\title{
Polish Public Libraries as Intermediaries in Accessing Information and Public Services (e-Government) in the Opinion of Librarians ${ }^{1}$
}

\author{
Mariusz Luterek \\ Department of Information Studies \\ Faculty of Journalism, Information and Book Studies \\ University of Warsaw
}

\begin{abstract}
Purpose/Thesis: The aim of this paper is to present opinions of the librarians on the role of public libraries as intermediaries in accessing public information and services in Poland.

Approach/Methods: The following hypothesis was adopted: public libraries have means and are willing to act as an intermediaries in accessing information and public services for citizens. The research hypothesis was verified with the results of a survey, which was sent to libraries in three voivodeships: Małopolskie, Mazowieckie and Świętokrzyskie.

Results and conclusions: The results prove that the level of interest of Polish public libraries in mediating the access to public electronic information and services is very low. In most cases the following approach was observed: users do not need it, there is not enough place in the library, the library lacks staff and there are too serious financial shortages.

Originality/Value: Data presented in this paper provide basic overview on the topic previously not being addressed in any research of that scope in Poland.
\end{abstract}

\section{Keywords}

Public information. Public services. e-Government. Public libraries. Poland.

Received: 10 December 2016. Revised: 10 January 2017. Accepted: 24 January 2017.

\section{Introduction}

Transformational, digital, or electronic, government (e-government) is the use of information and communication technologies in providing information and services by public authorities. The concept itself was named in the mid-1990s, as the result of introducing government to the World Wide Web, although computers were used in public sector much earlier (Scholl, 2010).

In Poland, since 2001, when Freedom of Information act was established, we could observe a very irregular growth of e-government. The rise of regional e-services portals and their nation-wide equivalent, the re-do of PESEL registry and, as a result, introduction of new ID, the enhancment of online presence of public offices - all led to bringing Polish public

1 This paper is based on a project, which was financed by the National Science Center Poland, through grant based on the Decision No DEC-2011/03/D/HS2/01124. 
sector to information society reality. However, it also meant that the government has to face the problem of digital divide and exclusion of some citizens in accessing public information and services. In this context it is important to ensure that people at risk of digital exclusion have appropriate opportunities to enter into relations with the public sector, for example by taking on the mediating functions by the public libraries.

Looking for inspirations on how to address this problem, one could take a look at the United States, where, starting from 1962 the system of Federal Depository Libraries FDLs) has been established. It's goal was, and still is, to facilitate access to public records, however, since early 1990-ties, main weight of their activities has shifted from paper to electronic documents. It wasn't an easy change - it took over a decade of arguments about the role of public libraries in electronic information dissemination (Keeping..., 2012).

\section{The Goal of the Paper and Research Methods}

The aim of this paper is to present opinions of the librarians on the role of public libraries as intermediaries in access to public information and services. For this purpose the following hypothesis was adopted: public libraries have means and are willing to act as an intermediaries in access to information and public services for citizens.

Verification of the research hypothesis was executed through a survey, which was subjected to libraries in three voivodeships: Lesser Poland and Świętokrzyskie Voivodeships (these are the province of respectively the biggest and the smallest development of Internet access in households in accordance with the report Social Diagnosis 2011) and Mazovian Voivodeship (chosen because of its internal differentiation). All municipal and rural-municipal public libraries in these provinces received invitations to participate in the study. Then the libraries that agreed to participate in the study were asked to complete a questionnaire, available in both paper and electronic form. The main objective of the survey was to investigate the possibility of performing of a given library as a mediator in access to information and public services, and the needs perceived by the library user and relationships (including existing barriers) with the relevant authorities.

The survey was divided into 6 sections:

(1) Imprint (10 questions concerning the library name, its location, and the area, the number of users and workstations).

(2) Familiarity with the problems of computerization of offices among librarians (one matrix question).

(3) Library and mediation in access to public services (in total 7 questions, including one open).

(4) Library and mediation to public information (5 questions, including one open)

(5) The library as an institution cooperating with other public institutions (7 questions, including 3 open).

(6) Conclusion and closing remarks (1 open question).

In addition, each question was accompanied by the field for adding an open comment. 


\section{The Course of the Study}

To ensure the comfort of participation in the survey the respondents were provided with the opportunity to direct contact with a person carrying out the study, both electronically and via a dedicated telephone line.

The interesting fact was, that on the second day after sending the invitations to participate in the study, there was the first telephone call from the anonymous librarian, who at the very beginning apologized for not introducing herself and not indicating where she was ringing from, but she insisted on not being recognized. As a result of 23 minute conversation (mostly one-way communication), it became clear that to ensure maximum representativeness of libraries the second message has to be sent to libraries underlining guarantee of full anonymity. For this purpose it was proposed to fill as the answer to selected questions the phrase "no data". This solution increased the number of completed questionnaires.

\section{Polish Libraries and e-Government}

\subsection{Location of Libraries Participating in the Survey}

The study involved a total of 112 libraries, including 5 branches, from three voivodeships (Lesser Poland, Mazovian and Świętokrzyskie), where positive answer to the invitation to participate in the survey was given by respectively 41,53 and 18 libraries. It should be noted that the rate of return places these three regions somewhat differently: the highest percentage of libraries participating in the study was reported in Lesser Poland voivodeship (21\%), followed by Świętokrzyskie (18\%) and Mazovian (16\%).

Fig. 1. Respondents by the size of the place of residence

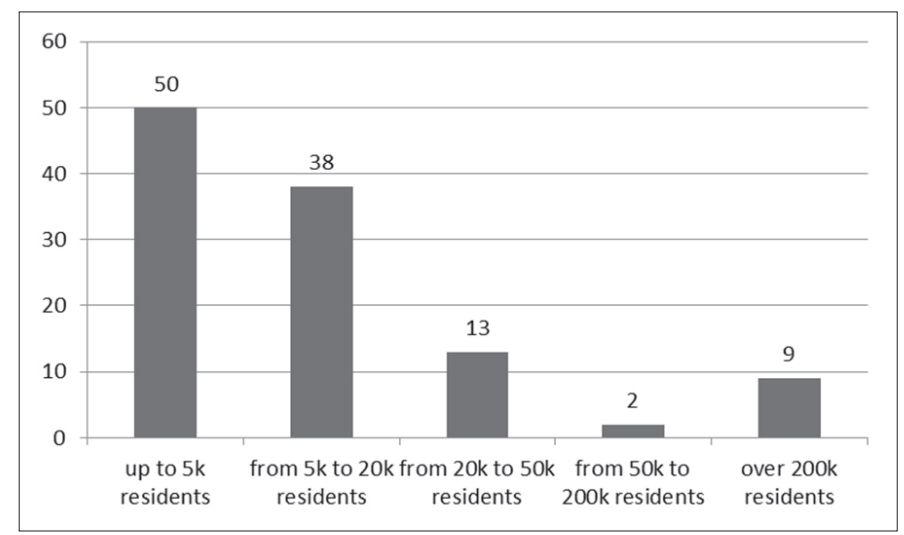

During the study it was possible to observe an interesting trend: the survey was filled more willingly by the libraries located in small towns -50 of them came from the place with the population up to 5 thousand, the next 38 - from 5 to 20 thousand. This gives a bit more than $78.5 \%$ (Fig. 1). What's more, the libraries from Warsaw very willingly participated in the study, while in case of Cracow the only respondents came from the Voivodeship 
Public Library in Kraków. During the interview conducted the attention was paid to a very traditional approach of libraries of Cracow to the scope of their activity, which explained their reluctance to participate in the study.

\subsection{Library Staff and Their Knowledge of e-Government}

One of the key aspects of the mediation by the public libraries in access to information and public services is to hire staff with appropriate knowledge and skills in this area. As the experience of other countries proves, in countries where libraries actively perform such a function, the standard is to have staff with appropriate competences.

In response to the question on how the representatives of libraries assess their knowledge on e-government, the largest part of them (47) said that it is poor (Fig. 2). When we take into account the 18 answers "I know from hearsay" and one indicating "I do not know what it is", it turns out that respondents from almost 59\% of libraries declare lack of adequate preparation substantive to perform such a function. It should also be noted that this question, as well as another in this part of the questionnaire lead the respondents to make kind of self-esteem, which as shown by the experience of all studies of this type usually leads to overestimating the percentage of declarations that the respondents see as more positive. For a better understanding of the phenomenon, we applied here two solutions.

Firstly, in the above question the term "e-administration" was used, instead of "e-government". It seems that in the Polish language usage, especially outside big cities, "e-government" could be an unfamiliar term. Moreover, the understanding of the term "e-administration" with a minimum knowledge of new technologies can be deduced on the basis of other words that begin with the prefix "e-" (e.g. e-mail).

Fig. 2. How do the librarians assess their knowledge in the area of e-administration?

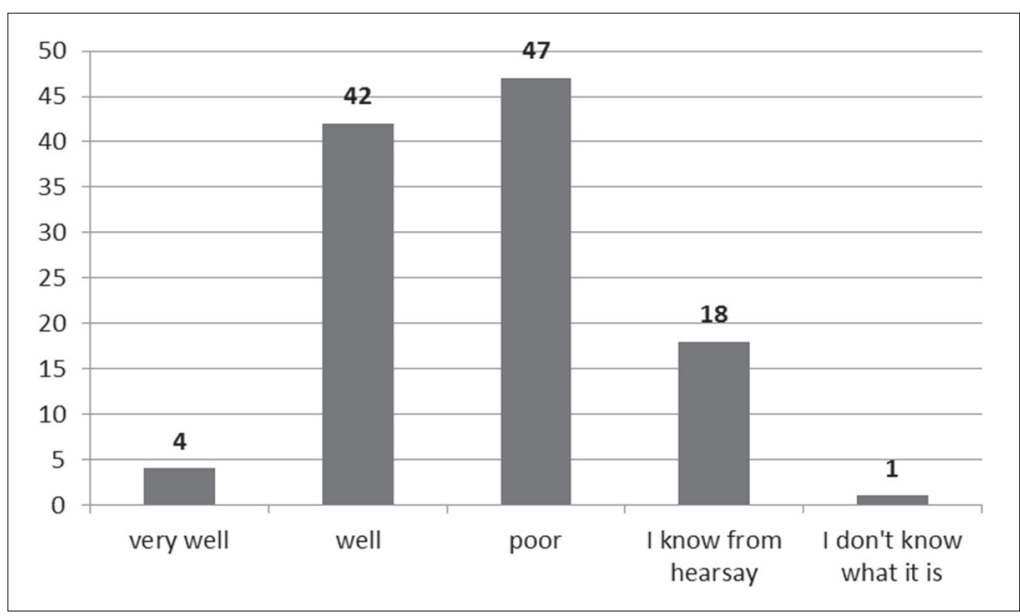

Secondly, a series of control questions were used, which allowed to verify self-general esteem declared by the respondents. The first question in this group was the question on the familiarity of the e-PUAP platform. It is a solution that is fundamental for the functioning of the system of electronic public services in Poland. Available from 2010 the e-PUAP is 
(or - eventually should be) an integrated access point to all the information and public services in Poland. So it is a solution far more complex than platforms available on the regional level. Meanwhile, 42 libraries declared good knowledge of e-administration, but only 28 equally good knowledge of the e-PUAP. At the same time, as many as in 19 cases the answer "I do not know what it is" was given (Fig. 3). It seems that as a more reliable source of information on the level of librarians' knowledge concerning e-administration should be considered just that question.

Fig. 3. How do the librarians assess their knowledge in the area of the e-PUAP?

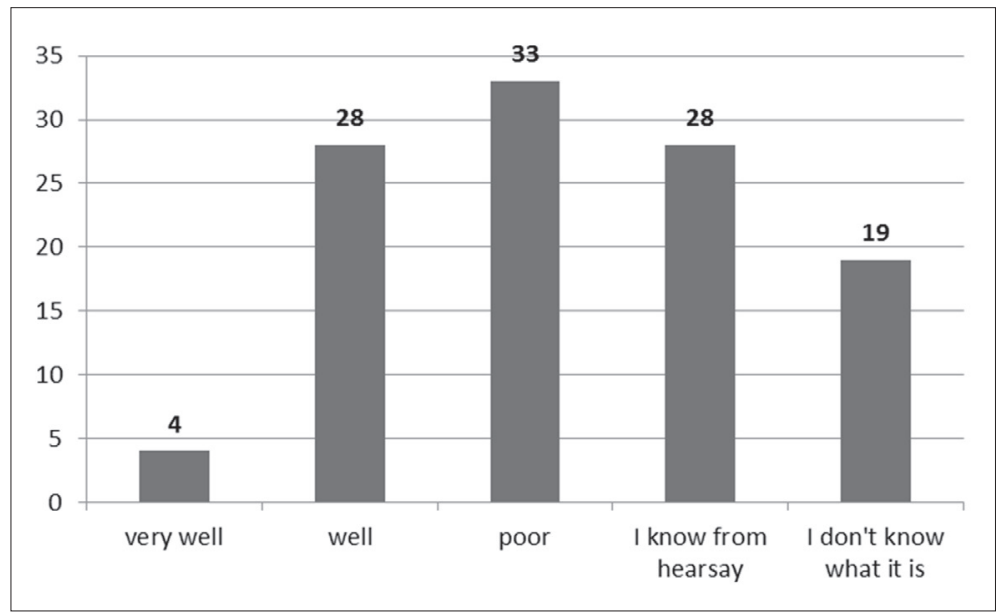

Another form of integrated access to public e-services are regional portals, created since 2002 under the joint strategy "Gates of Poland" ("Wrota Polski"). The first such services were created in Podlaskie and Lesser Poland Voivodeships. Compared to the e-PUAP platform these portals should be in the minds of users much more widespread. And indeed, in relation to the declarations obtained in respect of the e-PUAP platform, in the structure of responses to regional portals you can see here a slight shift to declarations indicating somewhat greater level of knowledge (Fig. 4). Interestingly, one library more than in the previous two questions, declared here a very good knowledge of the issue. This may indicate that in this library there is an employee who for some reason is particularly associated with the portal.

It should also be noted that the Mazovian Gates were made available in the usable form (with access to a true e-government) only in 2014, while Świętokrzyskie Gates functioned only for a very short time, so it could be expected here to get other answers.

Finally, the last important issue in the context of access to public services which we asked for, is familiarity with the so-called trusted profile. Information about it can be found at the starting site of the e-PUAP platform. As it can be read, it is a free mobile electronic signature, which should be used while using electronic services. After creating an account on the platform it is necessary to submit a request for profile confirmation. Then, you have to go to the nearest public office with the identity document. ${ }^{2}$ In practice without

\footnotetext{
${ }^{2}$ Since the research has been conducted, the Polish government has introduced a new solution alowing citizens to confirm trusted profiles through selected banks.
} 
a trusted profile you cannot effectively use the e-PUAP platform. So it is an informative verification question which proves the actual knowledge of the respondents. And so, as long as respondents from 28 libraries declared good knowledge of the e-PUAP, for the trusted profile there were only respondents from 20 libraries. The majority (respondents from 41 libraries) declared poor knowledge (Fig. 5). There may be several reasons for such results. Firstly, the respondents could considered "familiarity" as familiarity with the applied computer solutions. Secondly, declarations of the knowledge in the field of the e-PUAP platform could be overstated.

Fig. 4. How do the librarians assess their knowledge of the Polish Gates?

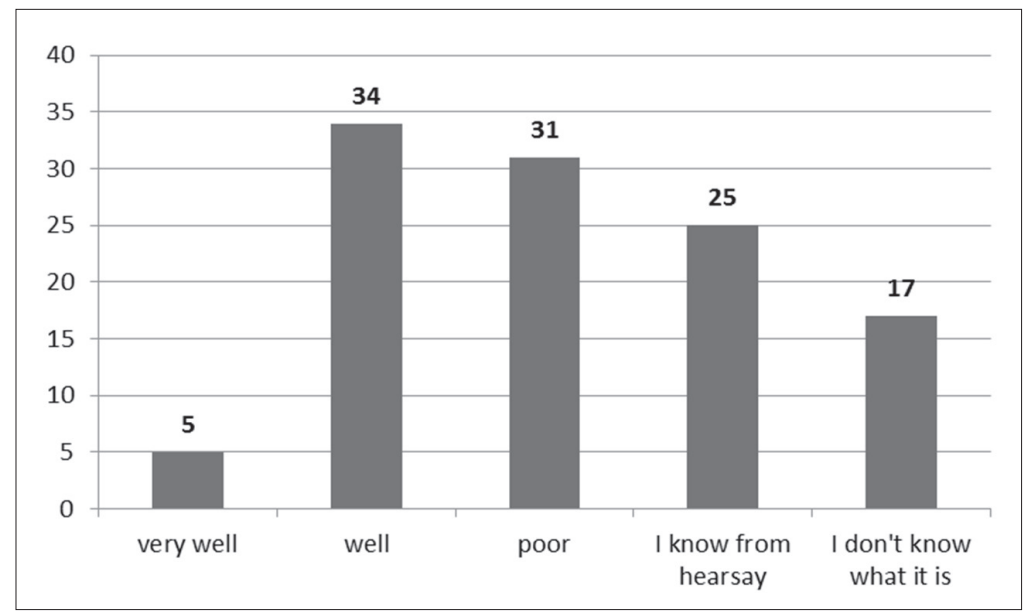

Fig. 5. How do librarians assess their knowledge of the trusted profile?

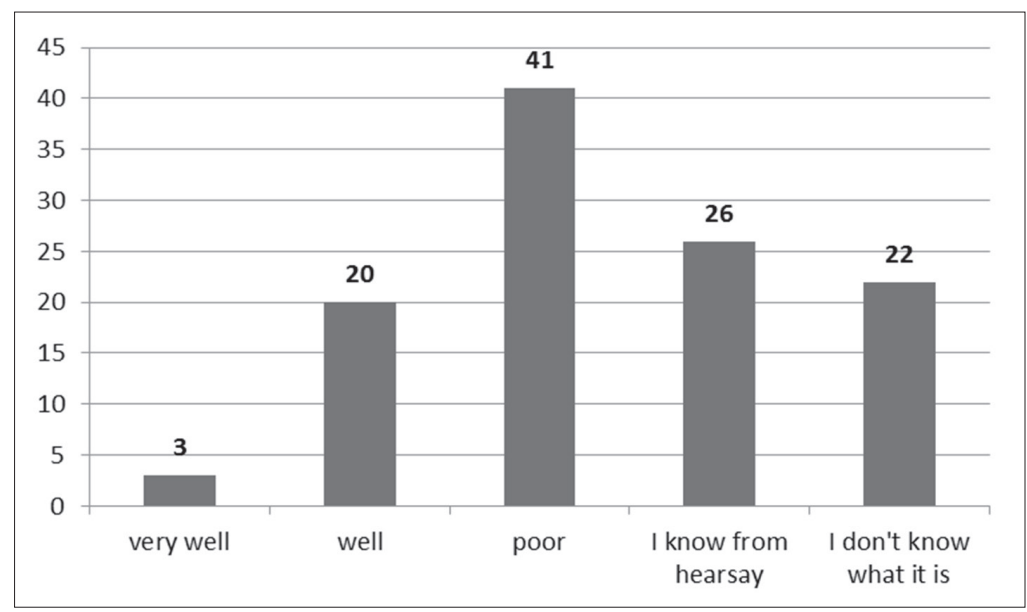

The Freedom of Information act is the main piece of legislation defining the rules concerning access to information which are being the responsibility of the public sector institutions, including public libraries. The declarations of knowledge of librarians in the case of this 
issue are much higher than in the case of public services (Fig. 6). Still few people show very good knowledge (only four), but good - already 56. Interestingly, 10 indicated that "I know from hearsay" and one - "I do not know what it is". Taking into account that the act dates back to 2001 and it regulates the important area of accessing information, it may surprise.

Fig. 6. How do librarians assess their knowledge of the Freedom of Information Act?



One of the latest trends in e-administration is a so-called open administration. In Poland, its result is a portal DanePubliczne.gov.pl created on the basis of the amended Freedom of Information Act, which established the rules of reusing public information. It takes the form of the Central Repository of Public Data, created to share data sets from the institutions of public administration. Its aim is to give means for citizens and business to create new solutions, applications and services. This is equivalent to sites such as the British data. gov.uk or the US www.data.gov. Re-use is indeed not a key issue from the point of view of the information activities of libraries, which explains why the obtained data show the limited interest in this subject among respondents, and above all - no need to update their knowledge in this area (see Fig. 7). A possible reason for this is the lack of interest of the citizens who use libraries.

One of the important issues related to e-administration is e-democracy. It covers issues such as e-consultations, e-regulation, or e-voting. They allow the citizens to e-participate in making various kinds of decisions at the central, regional and local levels. Initiatives of this type ensure the transparency of public institutions and give citizens the feeling that their opinion matters. Also libraries can use this type of solution (e.g. co-decision on the cultural program of the library).

According to the answers of the respondents, as many as 33 of them show that they only "hearsay" this issue and 16 declared their ignorance on the subject. However, it seems that such structure of responses as that shown in Fig. 8 is partly due to the use of the term e-democracy. During study visits in selected libraries it turned out that they often use e-questionnaires, which is the simplest form of e-consultation. 
Fig. 7. How do librarians assess their knowledge in the field of open administration / open data?

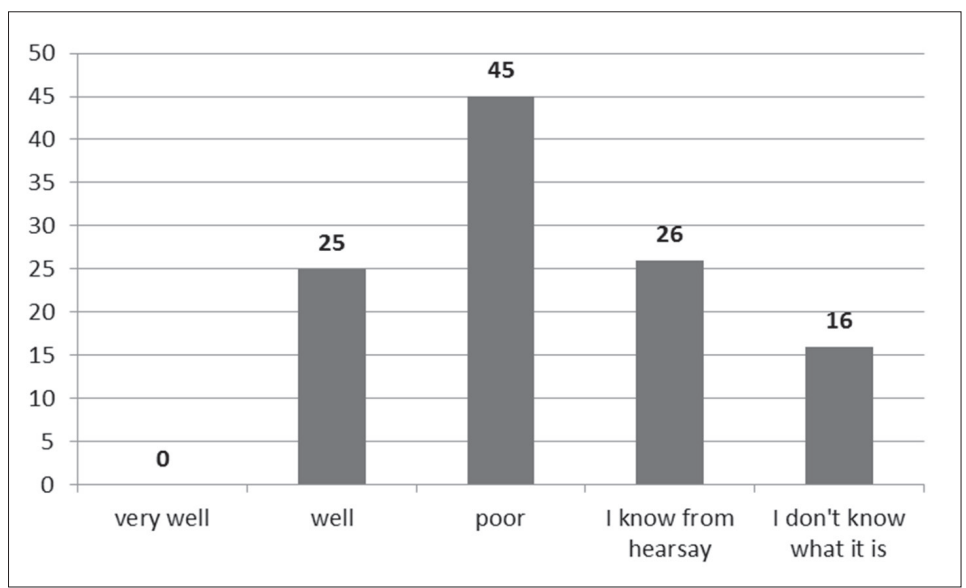

Fig. 8. How do librarians assess their knowledge in the field of e-democracy?

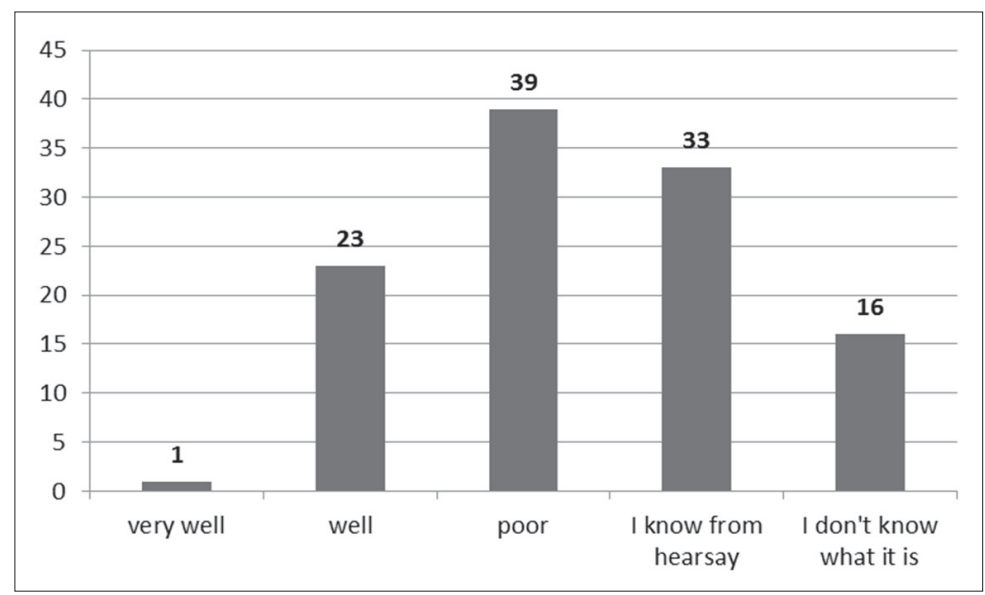

\subsection{Library and Mediation in Access to Public Services}

Strategies for the development of e-government in the European Union refer to a particular set of public services for citizens and business whose level of advancement is used to compare the progress of digitization of public administration since the existence of the strategy of development of the information society (eEurope). In the case of services to citizens they are: settlement with the tax office; services offered by employment offices; obtaining social benefits and pensions; obtaining personal documents; vehicle registration; obtaining a building permit, access to library catalogues; reporting to the police; changing the place of residence, services offered by the registry offices and submission of documents to higher education institutions (HEIs). During our study the respondents were asked whether in 
any of these services they offer assistance in their implementation. The most commonly declared service, as many as 99 times, was access to the catalogues of other libraries (see Fig. 9). However, taking into account the specific characteristics of library work, it may be surprising that 13 libraries do not offer assistance in this case.

The second indication is the submission of documents for the HEIs - 68 cases, the third the services offered by employment offices ( 47 times), then the settlement with the tax office (35) and signing up for a visit to the doctor. In other cases aid is offered sporadically, which can be easily explained by the lower level of computerization (or even unavailability online). The structure of the replies to this question can also indicate that librarians are more willing to provide assistance in the case of services which probably they had the opportunity to use before (which would explain a surprisingly large number of indications for services related to the submission of documents to study).

Among other services the respondents mentioned: printing applications; establishment of an e-mail, access to legal information Legalis; submission of documents to the secondary schools; obtaining insurance by those going to work abroad; electronic enrollment to kindergartens; checks with airline tickets and filling card capita. Some of them (setting up e-mail, e-account and check-in) can hardly be considered as public services, and their inclusion should be seen as a desire to show off to meet the needs of users.

Fig. 9. For which services available to citizens

the Library provides assistance in implementing them online?

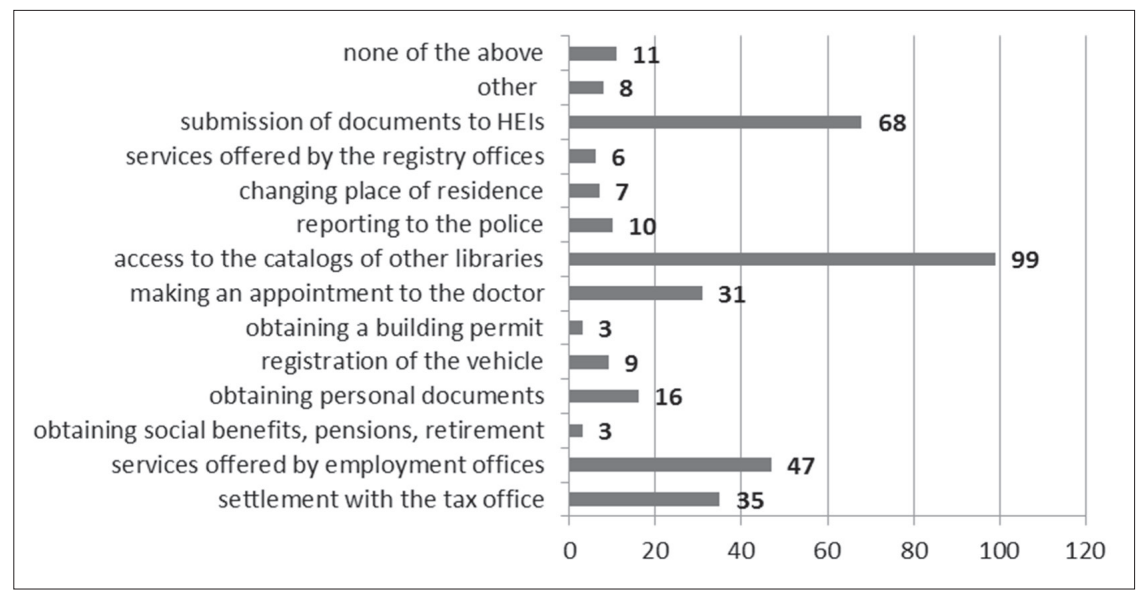

In one of the questionnaires turned up such a comment: "In the library we set up a Seniors Club. A dozen of senior citizens learned to use e-mail, buy in the online stores, transfer money to a grandson's account studying in another city. We help users who cannot cope with computers, e.g. scanning documents, downloading files from the Internet and editing them. We offer assistance in editing documents and formatting them". Similar statements were made by respondents from many libraries - as it is known, they are involved in the process of reducing the digital divide for quite some time.

In addition, it is worth noting that 11 libraries are not prepared to provide assistance for those services. Taking into account that there were only nine questionnaires that were 
anonymous by using the phrase "no data" questionnaires, filled in accordance with the declarations by the libraries that do not provide help, two libraries were not afraid of being assessed and gave complete data.

The tested libraries in a much lesser extent declare their readiness to assist in access to public services for entrepreneurs, than in the case of services for citizens. As many as 76 of them responded "none of the above". Less than one-fifth of the respondents pointed to "submitting data to the statistical office" and "settlement with the tax office" (see Fig. 10). This seems to be completely understandable - in Polish realities, differently than e.g. the US the libraries have little relationship with the business. Therefore, even these few indications should arouse positive surprise. Even in the case of such an institution as the Voivodeship Public Library in Kraków, which in its structure has a Reading Room of Business and European Information, during the study visit the approach, according to which the falling number of readers should be remedied by increasing the purchasing books was presented. The idea of expanding services did not occur, which is also understandable because of, as indicated, a high staff turnover.

Fig. 10. For which services for entrepreneurs the Library provides assistance in implementing them online?

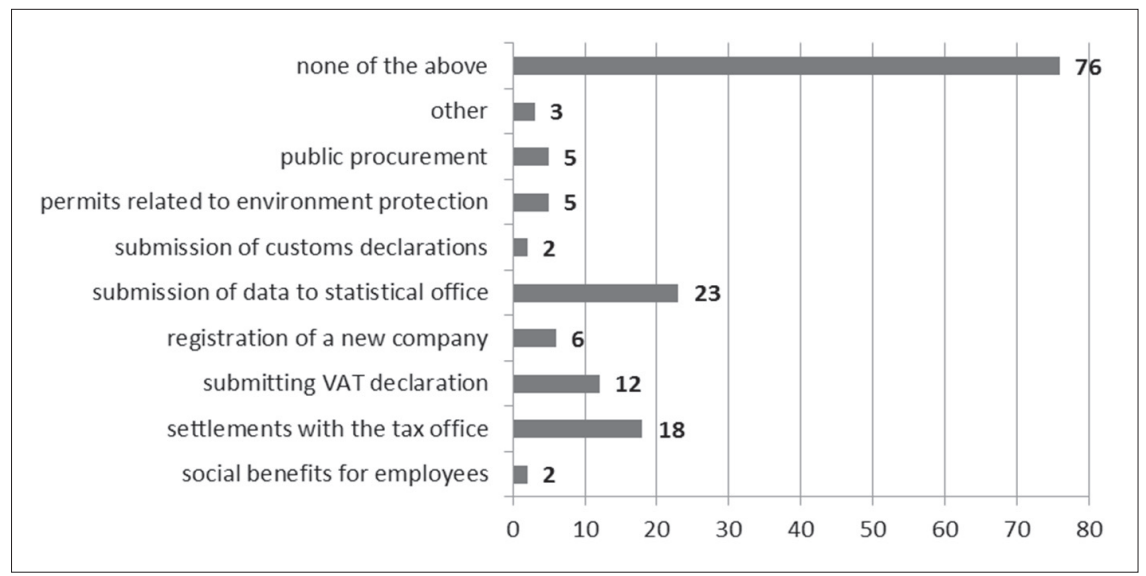

In the next section of the questionnaire the respondents were asked to indicate the level of interest in the implementation of individual support while realizing services to users of the libraries (Tab. 1). It turned out that help is most rarely sought in the case of services such as: building permits (95.5\% of responses - not at all), reporting to the police and changing the place of residence (94.6\% each); services offered by the registry offices $(93.8 \%)$, vehicle registration (92.9\%) and obtaining social benefits and pensions (90.2\%). It is worth noting, however, that these are the services for which the process of computerization was not launched at a time when the study was performed, or it was only possible to obtain forms. At the same time, however, in the case of some services, particularly those that are highly computerized or are particularly important in people's daily lives, the users' interest in assistance provided by librarians was observed. In particular it regards the service of settlement with the tax office - for more than $40 \%$ of libraries such inquiry appeared several times a year (the specifics of the service should be noticed - it is carried out only between 
January and April). This is of course one of the few public services in Poland, which allows the realization fully online in the whole country, without visiting the office. More often (35.7\% - several times a year, $21.4 \%$ - several times a month, $1.8 \%$ - several times a week) the support in dealing with labour offices is sought.

In the case of services for entrepreneurs the indications were much less optimistic. In the vast majority of them this type of question did not appear at all (indications "not at all" on a level above 90\%). The only exception occurred to be a service "transmission of statistical data" - 21 libraries received such requests several times a year, while one - several times a month. As it was already written, much less interest in the services for this group of customers is understandable due to the nature of Polish public libraries.

Tab. 1. For which of the following services users turn to the library for help in implementing them online?

\begin{tabular}{|c|c|c|c|c|c|c|c|}
\hline \multicolumn{2}{|c|}{ Never } & \multicolumn{2}{|c|}{$\begin{array}{c}\text { Very rarely } \\
\text { (a few times a year) }\end{array}$} & \multicolumn{2}{|c|}{$\begin{array}{c}\text { Rarely } \\
\text { (a few times a month) }\end{array}$} & \multicolumn{2}{|c|}{$\begin{array}{c}\text { Often } \\
\text { (a few times a week) }\end{array}$} \\
\hline Per cent & Amount & Per cent & Amount & Per cent & Amount & Per cent & Amount \\
\hline 1 & 2 & 3 & 4 & 5 & 6 & 7 & 8 \\
\hline \multicolumn{8}{|c|}{ Settlements with the tax office for citizens } \\
\hline $52.7 \%$ & 59 & $42.9 \%$ & 48 & $4.5 \%$ & 5 & $0 \%$ & 0 \\
\hline \multicolumn{8}{|c|}{ The services offered by employment offices } \\
\hline $41.1 \%$ & 46 & $35.7 \%$ & 40 & $21.4 \%$ & 24 & $1.8 \%$ & 2 \\
\hline \multicolumn{8}{|c|}{ Obtaining social benefits, pensions, retirement } \\
\hline $90.2 \%$ & 101 & $6.3 \%$ & 7 & $36 \%$ & 4 & $0 \%$ & 0 \\
\hline \multicolumn{8}{|c|}{ Obtaining personal documents (identity card, passport, driving license) } \\
\hline $89.3 \%$ & 100 & $7.1 \%$ & 8 & $3.6 \%$ & 4 & $0 \%$ & 0 \\
\hline \multicolumn{8}{|c|}{ Vehicle registration } \\
\hline $92.9 \%$ & 104 & $6.3 \%$ & 7 & $0.9 \%$ & 1 & $0 \%$ & 0 \\
\hline \multicolumn{8}{|c|}{ Obtaining a building permit } \\
\hline $95.5 \%$ & 107 & $3.6 \%$ & 4 & $0.9 \%$ & 1 & $0 \%$ & 0 \\
\hline \multicolumn{8}{|c|}{ Making an appointment to the doctor } \\
\hline $67 \%$ & 75 & $28.6 \%$ & 32 & $2.7 \%$ & 3 & $1.8 \%$ & 2 \\
\hline \multicolumn{8}{|c|}{ Access to the catalogs of other libraries } \\
\hline $7.1 \%$ & 8 & $17 \%$ & 19 & $37.5 \%$ & 42 & $38.4 \%$ & 43 \\
\hline \multicolumn{8}{|c|}{ Reporting to the police } \\
\hline $94.6 \%$ & 106 & $3.6 \%$ & 4 & $1.8 \%$ & 2 & $0 \%$ & 0 \\
\hline \multicolumn{8}{|c|}{ Changing the place of residence } \\
\hline $94.6 \%$ & 106 & $4.5 \%$ & 5 & $0.9 \%$ & 1 & $0 \%$ & 0 \\
\hline \multicolumn{8}{|c|}{ Services offered by the registry offices } \\
\hline $93.8 \%$ & 105 & $5.4 \%$ & 6 & $0.9 \%$ & 1 & $0 \%$ & 0 \\
\hline \multicolumn{8}{|c|}{ Submission of documents for HEIs } \\
\hline $33.9 \%$ & 38 & $55.4 \%$ & 62 & $8 \%$ & 9 & $2.7 \%$ & 3 \\
\hline \multicolumn{8}{|c|}{ Social benefits for the employees } \\
\hline $92.9 \%$ & 104 & $6.3 \%$ & 7 & $0.9 \%$ & 1 & $0 \%$ & 0 \\
\hline
\end{tabular}




\begin{tabular}{|c|c|c|c|c|c|c|c|}
\hline 1 & 2 & 3 & 4 & 5 & 6 & 7 & 8 \\
\hline \multicolumn{8}{|c|}{ Settlements with the tax office for entrepreneurs } \\
\hline $94.6 \%$ & 106 & $4.5 \%$ & 5 & $0.9 \%$ & 1 & $0 \%$ & 0 \\
\hline \multicolumn{8}{|c|}{ Submitting VAT declarations } \\
\hline $95.5 \%$ & 107 & $3.6 \%$ & 4 & $0.9 \%$ & 1 & $0 \%$ & 0 \\
\hline \multicolumn{8}{|c|}{ Registration of a new company } \\
\hline $92 \%$ & 103 & $7.1 \%$ & 8 & $0.9 \%$ & 1 & $0 \%$ & 0 \\
\hline \multicolumn{8}{|c|}{ Submission of data to the statistical office } \\
\hline $80.4 \%$ & 90 & $18.8 \%$ & 21 & $0.9 \%$ & 1 & $0 \%$ & 0 \\
\hline \multicolumn{8}{|c|}{ Submission of customs declarations } \\
\hline $97.3 \%$ & 109 & $1.8 \%$ & 2 & $0.9 \%$ & 1 & $0 \%$ & 0 \\
\hline \multicolumn{8}{|c|}{ Permits related to environment protection } \\
\hline $94.6 \%$ & 106 & $4.5 \%$ & 5 & $0.9 \%$ & 1 & $0 \%$ & 0 \\
\hline \multicolumn{8}{|c|}{ Public procurement } \\
\hline $90.2 \%$ & 101 & $9.8 \%$ & 11 & $0 \%$ & 0 & $0 \%$ & 0 \\
\hline
\end{tabular}

Fig. 11. In your opinion, in which online services for citizens would the help of librarians meet with interest of the library users?



In the next question, which functioned as verification in the context of other questions in this section of the questionnaire, the librarians were asked to express their opinion about which online services for citizens help given by the librarians would meet the interest of the users. Obtained answers are basically in line with what respondents declared earlier (Fig. 11). In this context two of the comments posted by librarians regarding this question are worth citing (original syntax):

In each of these cases, provided that the libraries will be able to have an adequate number of staff, of course prepared for such work. So far on rural areas I cannot imagine that - in the one-person library - when to do it and which regular activities of a librarian should be omitted? And what about the electronic boxes, e.g. of the municipal offices or municipal social welfare center, for others not to mention? 
We suppose that all issues (with the exception of the building permit, which is impossible to deal with through the Internet) a Polish citizen would like to settle in the library, but it is not easy and you need to deal with them yourself. Moreover, none of the librarians will not take responsibility for assistance in providing the above mentioned services, because they would become a scapegoat. Referring to libraries in other countries has nothing to do with the Polish reality: in Denmark baby's room in the library is bigger than our entire library.

While the two comments are not particularly positive in the context of the role of intermediary by the libraries in this range, their content is evidence that in some libraries a high level of awareness of the issues and the challenges facing them may be observed the reservations are fully justified and reasonable.

Fig. 12. In your opinion, in which online services for entrepreneurs would the help of librarians meet with interest of the library users?

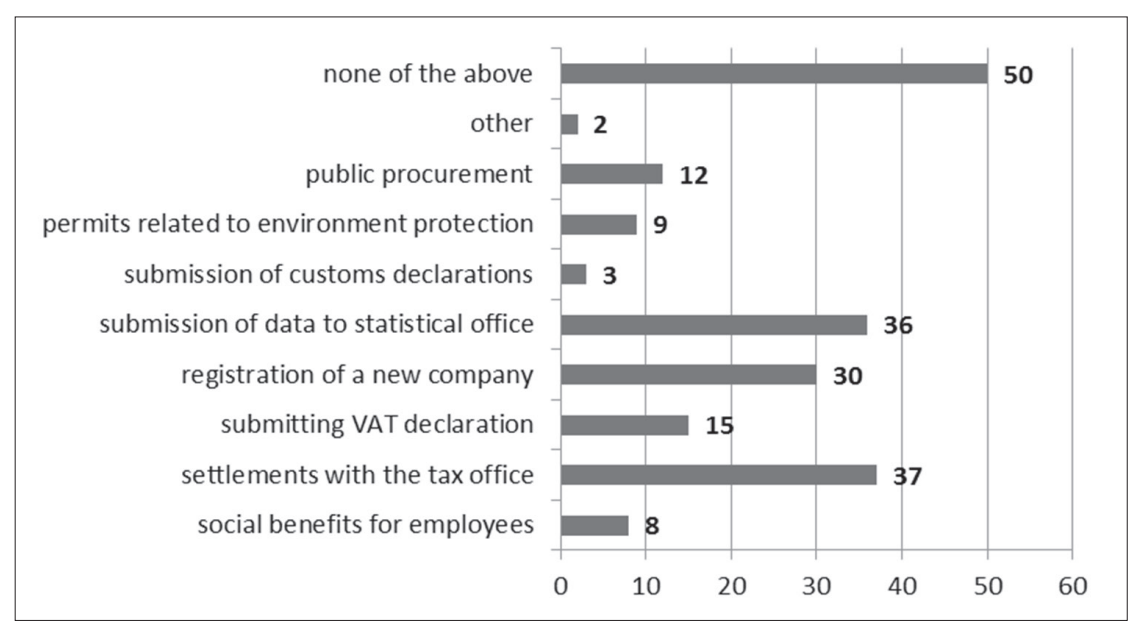

Interestingly, only in this part of the questionnaire there are more optimistic answers in the context of mediation by libraries in access to services G2B (Fig. 12). Thus, respondents from 37 libraries sees the potential for interest in the service "settlement with the tax office"; 36 - "submission of data to the statistical office," and 30 - "registration of a new company." Only representatives of 50 libraries indicated the option "none of the above", which is a very positive surprise.

Finally, the respondents were asked about in what kind of public services in their opinion their library should mediate. The question was open and was aimed at giving an opportunity to demonstrate to other ongoing activities in this area. Among the indications are, among others, as follows:

we had the opportunity to participate in the project "Work it out with the library" and this activity is closest to us

which proves that such programs are fulfilling their function and broaden the range of library activity;

the library can mediate virtually in every service, but after training librarians or receiving training materials / information for individual services 
which shows that the transfer of information materials to the libraries should probably be institutionalized and formalized, as it is the case of e.g. the United Kingdom;

information about the town and municipality - information on services in the municipality;

or

a library could mediate in providing information concerning local issues, e.g. kindergartens, schools, social welfare center and other operating in this town institutions

which means involvement of the library into access to local information.

There were also numerous indications regarding particular services, for example

access to the catalogs of other libraries and access to official documents - including those related to the protection of the environment, taxes and building permits and vehicle registration

and in the services not included in the multiple choice questions, for example

determining the ownership of real property; interpretation of judicial decisions,

or

settlement payments for farmers in the Agency for Restructuring and Modernization of Agriculture

that service may be of particular interest in rural areas.

There were numerous indications of activities coming within the traditional area of interest of libraries - culture (e.g.: services to promote culture and reading);

In 12 cases respondents used sign „X” which allowed to omit the obligation to fill this answer.

There were also more general responses, e.g .:

Our library has long been a service company. Currently, we are the only place in the municipality where you can use a computer and a broadband Internet connection for free, write a document and print it. For a nominal fee (because our income cannot exceed the value of the materials used and the cost of depreciation of equipment) you can copy, bind, send a fax, but first find the right phone number;

or

Computer courses for seniors are gaining in popularity. We learn how to use web browsers, set up an Internet e-mail and its use. We talk about subjects that particularly interesting for seniors: online shopping, virtual tours, videos, music, books on the Internet. It happens often that users who want to send a document over the Internet, but do not know that they must have an e-mail account come to the library. Then we help, show, learn ... and these are our public services.

In addition, responses pointed to the difficulties arising due to factors beyond the library, e.g.:

opposite the library there is a Municipal Office, any services of this kind are dealt with in this office

which is not entirely true, but it may explain the lower interest in certain services. Another comment was that type:

In our municipality there is only a public library in which one employee is employed on a part-time who performs all the functions. 
The last question in this part of the questionnaire concerned the main difficulties in mediating of the public libraries in access to information and public services (Fig. 13). Indications can be divided into two groups: internal barriers and external barriers. In the first one the most frequently indicated barriers was too small number of employees ( 84 libraries), insufficient knowledge of workers (62), or financial constraints (59) and housing constraints (46). Interestingly, most rarely indicated answer was insufficient number of computers with Internet access for users, which proves the success of computerization programs implemented for years in Polish libraries. In addition, it is worth noting that during the study visits British libraries were usually small, with limited staff (1-2 people on the shift), and still these are institutions thriving in this area. In turn, French libraries, with a lot of space and a large staff do not have such offer. This can be concluded that real barriers may be in a) the mentality of librarians, b) external factors. The latter include determinants of demand - a lack of interest on the part of users (77 responses) and relations with the authorities - the perception of libraries as only the lending institution of books (58).

Fig. 13. In your opinion, what is the main problem / barrier

in the performance of mediation in access to public services by your Library?

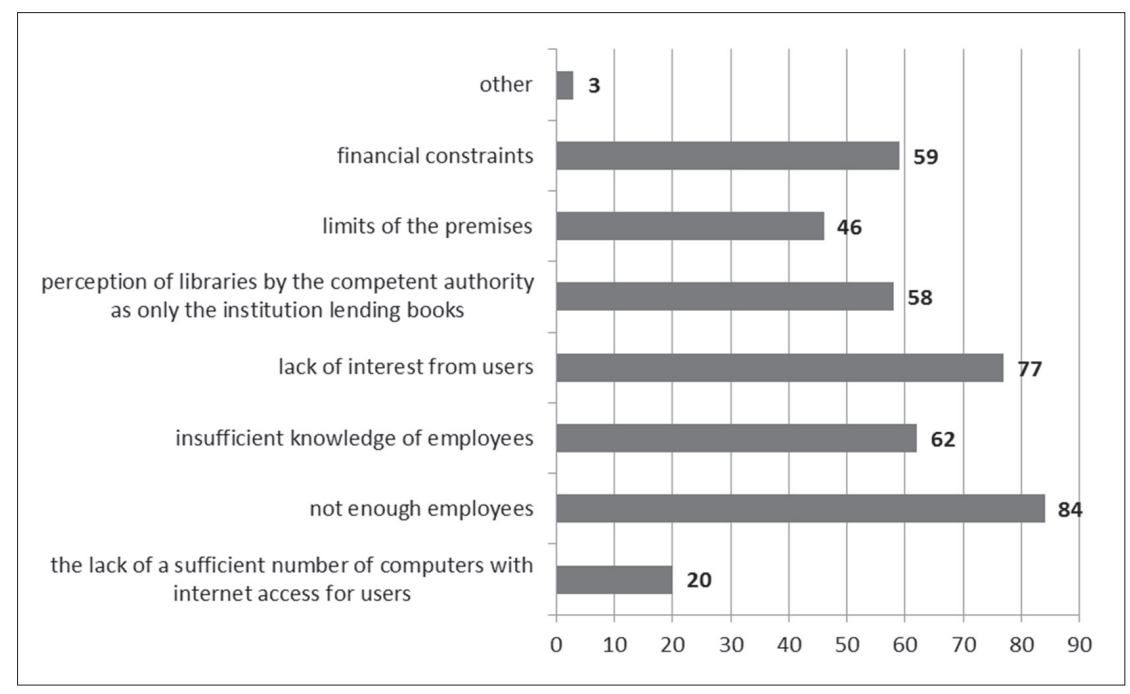

Librarians supplemented their choices by comments. It is worth mentioning two of them:

\footnotetext{
The main barrier is the insufficient number of employees in relation to the duties already performed. To make efficient, proposed by you services each facility should hire a person at least half-part time. Otherwise it makes no sense to impose additional burden on the libraries. Such services no one will be able to perform. Please note that in small libraries an employee must within a few hours of work: service readers, provide information, develop collections, help in using the Internet, conduct cultural activities, documentation, statistics, perform technical work and so on.
}

A library mediates in access to public services by providing unpaid places with access to the Internet, provides space and technical capabilities to use a computer. The librarian cannot be a specialist in everything - after all, in the customs office, no one can help with problems with cutting down the trees and in the tax office the employees will not search books to the thesis. 


\subsection{Library and Mediation in Access to Public Information}

The fifth part of the questionnaire was devoted to mediation by libraries in access to public information, which can be understood as local information or as presented in the Freedom of Information Act, e.g. in the Public Information Bulletin. As it was written, some indications in this area appeared in the comments of respondents to questions in other parts of the questionnaire.

The first question in this section was open and said: "If the library offers help in finding public information online (information provided by public institutions), what information is most commonly of interest to users?" Because it was not an obligatory question, it was completed by only 84 respondents $(75 \%)$, although in fact it looks a little worse: some entries were "not applicable", "hard to say" or even "I do not know".

In the responses most frequently appeared: information on work places, insurance and repeating the declaration on public services. This is surprising in the context of the declaration concerning the familiarity with the act on access to public information. This can be explained by lack of demand, but also for part of the declarations some of the obtained answered should here be considered as a method to verify the knowledge of the act. In the responses of the respondents the Public Information Bulletin appeared only once, as only once appeared the opening hours of other offices. In return, they pointed to banking or tourist services, which are not within the range of the public sector.

It should be reminded that this study was exploratory in nature, so the questionnaire did not hold educational function and was intended to verify the actual knowledge / awareness of the respondents in this area.

In response to a question about whether the library offers help in understanding / interpretation of public information found in the Internet, only 42 times "yes" answer was given. It seems that this is an issue that will require further, in-depth research. On the one hand, such a large number of "no" answers can be explained by the lack of willingness of librarians to take on the responsibility for any consequences resulting from errors of interpretation. On the other hand, one should try to understand what librarians understand by the interpretation. Is finding information on the Internet with the help of library staff (and including the definition of the found answers as relevant) is not a form of interpretation?

When the respondents were asked about whether they conduct courses / trainings / workshops facilitating the use of online public services we also achieved a surprisingly small number of positive responses - only 20 . Comments added to other questions repeatedly referred to the courses for seniors, computer courses, opening an e-mail account etc. This means that the libraries feel much more confident in the area of spreading computer competences, than in the case of information competences.

\subsection{Library as an Institution Cooperating with Other Public Institutions}

The last group of questions contained in the questionnaire concerned the issues related to the forms of cooperation of public libraries with other public institutions. According to the declarations of the respondents, the most common cooperation covers relations with educational institutions - 90 indications. As the second group they indicated the district offices, municipalities etc. (58), but in this case it is associated with treating by librarians 
formal and legal relationships with the competent authority as the cooperation. Then they indicated: non-government organizations (50 times), employment offices (35), district offices (25) and tax offices. In particular, cooperation with units of employment offices and tax offices here has a positive connotation - the comments included in this question indicate that they are mostly various types of meetings / shifts of representatives of these offices in the library. Among others emerged: centers of culture, municipal social welfare centers, volunteer fire brigade, the house of social assistance (Fig. 14).

On the question about the nature of this cooperation, the respondents gave various answers, including a few rare indeed related to the subject of the study:

the library provides the Employment Office space for advice or training;

the organization of internships, practices, meetings, trainings, help in writing applications, choosing professional predispositions, finding work in the project Work it out with the library;

the implementation of joint projects for seniors, obtaining beneficiaries for programs, help in the settlement of grants for Non-government organizations, assistance in carrying out public consultations;

"trainings, courses, workshops, filling in tax declarations in libraries by employees of the tax office.

Most often, however, respondents pointed to the cooperation within traditionally understood activity of the library, for example:

the most systematic is the cooperation with a kindergarten, children participate in activities conducted by the librarian under the name ,hours with a book”, in competitions, they watch educational films, we prepare for them multimedia presentations; inter-school competitions are held; we organize meetings with authors; we wrote and realized grant under the name of Planning and career-library supports the student.

Fig. 14. Which of the following institutions does the Library cooperate with?

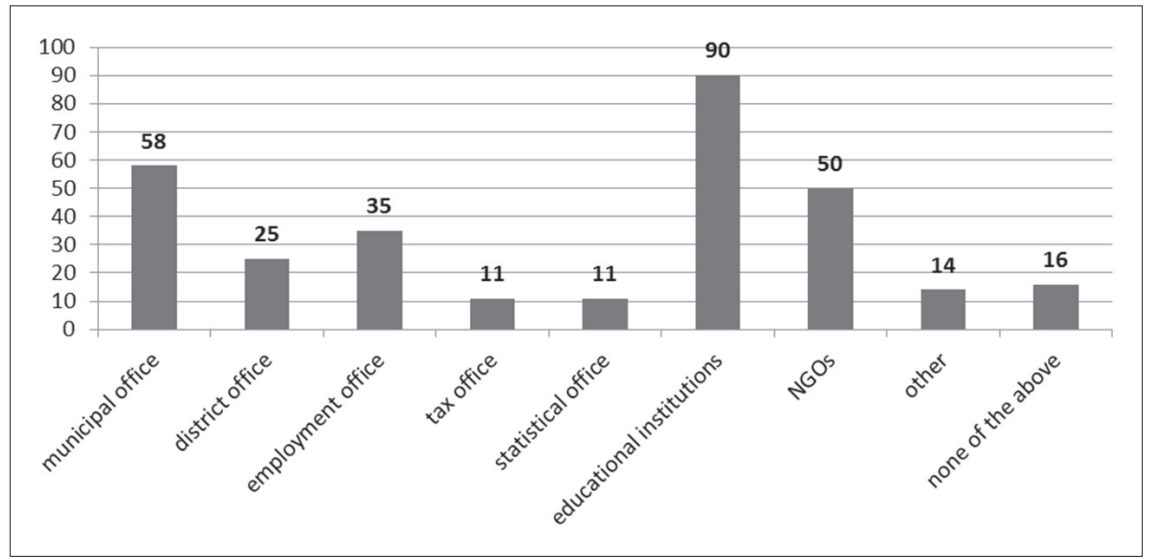

Interestingly, the most common initiators of such cooperation are the libraries themselves. For the question which public institutions offered in the past cooperation, the most often response was "none of the above." The comments also make it clear that the librarians usually come with their ideas outside and look for partners for cooperation. 
If such a proposal is made, it is usually made by educational institutions (50 responses), non-governmental organizations and district authorities / municipalities etc. (26 for each) and employment offices (16).

Interesting conclusions may be made after interpretation of the answer to the question concerning which institutions the library would like to cooperate with in the future. As many as 38 of respondents declared that with any of the above. By correlating this with the fact that only 16 libraries currently do not carry any cooperation, it means that 22 libraries currently operating with public institutions do not intend to continue these initiatives. The interest of libraries included in particular employment offices (38 responses), educational institutions (35), district offices (24), and non-government organizations (21).

Finally, on the question whether in the library there are meetings of users with representatives of other public institutions are conducted, only 39 respondents answered positively. Most often they were representatives of employment offices, municipal offices, tax offices, police and municipal police.

\section{Conclusions}

The conducted study was exploratory and allowed to verify current knowledge functioning among Polish specialists dealing with these issues. As shown, the level of interest of Polish public libraries arranging access to information and public services is very low. Taking into account that in the study, surpassingly, overrepresentation of the more active institutions occurred, the situation may in fact look a bit worse.

On the other hand, carried out in the second phase of the study the series of visits showed that libraries sometimes do not even know that they serve such activities, and are even a role model of good practice. A case in point was the City Library in Oświęcim, which can be a role model for other libraries of similar size. As part of its services was, among others, Local Information website - as we can read on the website of the library:

[it is] a database collecting information on institutions, associations, organizations and people that are important from the point of view of the residents of Oświęcim, with a calendar of significant events. This website has a form of responsive website. This means that every user of a smartphone, computer or tablet with Internet access can view it on their device (http://mbp-oswiecim.pl/oswiecimska-informacja-lokalna/, 20.11. 2016).

Besides, the library runs Radio Oświęcim, where are broadcast on the local news - for example, during a study visit information of the day was the approaching deadline for payment of the tax on the dog.

In most cases was observed an approach which can be summarized as follows: users do not need it, in the library there is not enough place, no enough employees and there are too serious financial shortages. When we correlate this with visits to libraries, e.g. in London (struggling with exactly the same problems) and libraries, e.g. in French Montpellier (modern, rich, rich in human resources and premises), it turns out that the main factor for engaging libraries in innovative solutions is seeing only the traditional role of the library by all stakeholders: users, librarians and government officials. Only a few try to break common stereotypes in this regard. 


\title{
References
}

Keeping America Informed (2012). Washington D.C:The U.S. Government Printing Office.

Scholl, H. J. (2010). Electronic Government: A Study Domain Past its Infancy. In: H. J. Scholl (ed.) e-Government: Information, Technology and Transformation. Armonk, NY: M.E. Sharpe, 11-32.

\section{Polskie biblioteki publiczne jako pośrednicy w dostępie do elektronicznych informacji i usług publicznych (e-Government) w opiniach bibliotekarzy}

\begin{abstract}
Abstrakt
Cel/Teza: Celem artykułu jest zaprezentowanie wyników badania opinii bibliotekarzy w zakresie możliwości pośredniczenia przez biblioteki publiczne w dostępie do informacji i usług publicznych (e-Government) w Polsce.

Koncepcja/Metody badań: Na potrzeby badania przyjęto następującą hipotezę badawczą: Biblioteki publiczne mogą pełnić funkcję pośrednika w dostępie do informacji i usług publicznych dla obywateli. Weryfikację hipotezy przeprowadzono poprzez badanie ankietowe bibliotek publicznych w trzech województwach: małopolskim, mazowieckim oraz świętokrzyskim.

Wyniki i wnioski: Uzyskane wyniki dowodzą, że poziom zainteresowania pełnieniem funkcji pośrednika w dostępie do informacji i usług publicznych online wśród bibliotekarzy jest niski. W większości przypadków jako powód tego stanu rzeczy podawano niewystarczającą powierzchnię użytkową, ograniczoną liczbę pracowników oraz niedostateczne środki finansowe.

Oryginalność/Wartość poznawcza: Rezultaty przedstawione w artykule odnoszą się do tematyki nie podejmowanej wcześniej w polskiej literaturze naukowej.
\end{abstract}

\section{Słowa kluczowe}

Informacja publiczna. Usługi publiczne. e-Government. Biblioteki publiczne. Polska.

MARIUSZ LUTEREK, PhD, is Assistant Professor at the University of Warsaw (Department of Information Studies, Faculty of Journalism, Information and Book Studies). He is the author of numerous publications on e-government, including the book e-Government. Public information systems (Warsaw, 2010). He was the leader of the project "Libraries as intermediaries in access to public information and services" - funded by Polish National Science Center.

Contact to the Author:

m.luterek@uw.edu.pl

Department of Information Studies

Faculty of Journalism, Information and Book Studies

University of Warsaw

Nowy Świat 69

00-046 Warszawa 